ROCZNIKI PEDAGOGICZNE

Tom 11(47), numer 2 - 2019

DOI: http://dx.doi.org/10.18290/rped.2019.11.2-0

\title{
OD REDAKTORA NAUKOWEGO
}

Edukacja wczesnoszkolna jest etapem edukacyjnym, który głęboko zapada w pamięć każdego człowieka. Należy również podkreślić, że stanowi ona przedmiot dynamicznie rozwijających się zainteresowań zarówno przedstawicieli nauki, oświaty oraz praktyków.

W edukacji wczesnoszkolnej pojawiają się nowe teorie i orientacje badawcze o charakterze teoretycznym i empirycznym. Zakończyła się dyskusja nad podstawą programową edukacji wczesnoszkolnej. Trwa dyskusja nad koncepcją kształcenia przyszłych nauczycieli. Na treść, zakres i formę dyskusji oraz jej efekty ma wpływ wiele czynników. Wśród nich należy wymienić przemiany polityczne, społeczne, gospodarcze, kulturowe, procesy i zjawiska globalizacji, migracji, wielokulturowość, rozwój nowych technologii informacyjno-komunikacyjnych. Ważnym czynnikiem jest rozwój polskiej myśli pedagogicznej z zakresu: pedagogiki wczesnoszkolnej, pedagogiki szkolnej, kultury szkoły, pedagogiki rodziny, dydaktyk, metodyk szczegółowych i innych dyscyplin naukowych.

Kolejnym istotnym czynnikiem jest współpraca międzynarodowa wielu ośrodków akademickich w kraju, która owocuje powstaniem nowych trendów w teorii i praktyce. Stąd wyrasta potrzeba podejmowania w obszarze teorii, jak również praktyki - działań upowszechniających nowe lub zmodyfikowane teorie w pedagogice wczesnoszkolnej i związane z nią rozwiązania praktyczne we wczesnej edukacji.

Autorzy przygotowanej publikacji podejmują dyskusję nad aktualnymi problemami edukacji wczesnoszkolnej i prezentują elementy teorii i praktyki wzbogacając dorobek pedagogiki wczesnoszkolnej.

W przedstawionym opracowaniu punktem wyjścia teoretycznych analiz jest artykuł Teresy Parczewskiej ukazujący uwarunkowania, możliwości i potrzeby fenomenologii w pedagogice. Autorka na tle ogólnych rozważań dotyczących fenomenologii ukazuje jej możliwości i ograniczenia prowadzenia badań fenomenologicznych oraz wskazuje jej zastosowanie w praktyce. 
Kinga Kuszak prezentuje „panoramę” problemów teoretycznych i praktycznych będących przedmiotem badań teoretycznych i empirycznych związanych z kształceniem nauczycieli w zmieniającej się rzeczywistości XXI wieku.

Przedmiotem rozważań Krystyny Chałas jest fenomen osoby nauczyciela i ucznia, zwłaszcza jej przymioty, jako źródło zadań, celów, treści i efektów w edukacji wczesnoszkolnej. Artykuł daje personalistyczne tło dla artykułu ks. A. Maja, w którym przedmiotem analiz autora jest duchowość dziecka wedukacji wczesnoszkolnej.

S. Iwona Lis $\mathrm{w}$ artykule, pt. Przestrzeń aksjologiczna $w$ nauczaniu religii dzieci w wieku wczesnoszkolnym, zwraca uwagę na sposób, w jaki wartości religijne poszerzają przestrzeń aksjologiczną małego dziecka.

Mykola Pantiuk, Tetiana Pantiuk, Liliia Stakhiv, Liliia Vovk w swoim opracowaniu poruszają problematykę społecznych uwarunkowań edukacji przedszkolnej i wczesnoszkolnej na Ukrainie i w Europie.

Jolanta Andrzejewska w artykule, pt. Sytuacje edukacyjne w szkole zogniskowane na uczeniu się wychowanka, podejmuje problematykę uczenia się. Ponadto wyodrębnia zadania nauczyciela edukacji wczesnoszkolnej, jako kreatora przestrzeni edukacyjnej zogniskowanej na procesie uczenia się $\mathrm{w}$ powiązaniu z teorią konstruktywizmu poznawczego i społecznego.

Przedmiotem analiz Anny Zamkowskiej są kompetencje nauczyciela wczesnoszkolnej edukacji włączającej. Autorka podejmuje niezwykle ważne zagadnienia ze względu na działania reformatorskie w polskiej szkole. Ważnym walorem opracowania jest odniesienie aksjologiczne kompetencji.

W tym samym nurcie rozważań znajduje się artykuł Joanny Majchrzyk-Mikuły i Barbary Grabarczyk. Autorki przedmiotem analiz czynią profilaktykę logopedyczną w praktyce edukacyjnej nauczyciela edukacji wczesnoszkolnej, eksponując postawę nauczyciela wspierającego.

Artykuł Ronit Bassan-Cincinatus i Dorit Patkin zawiera praktyczne rozwiązania dotyczące kształcenia matematycznego dzieci. Natomiast autorki: Stanisława Nazaruk, Ewa Tokarewicz oraz Anna Klim-Klimaszewska w swoim opracowaniu prezentują wyniki badań nad poziomem rozwoju grafomotorycznego dzieci 5-letnich w aspekcie gotowości do podjęcia nauki pisania. Albert Szułczyński przedmiotem swoich analiz czyni możliwość wykorzystania metody E. Gordona w edukacji muzycznej dzieci w wieku wczesnoszkolnym.

Przedstawione opracowanie powstało na gruncie międzynarodowej konferencji, pt. „Polska pedagogika wczesnoszkolna: teoria - badania - praktyka. Wiodące kierunki i szkoły naukowe", zorganizowanej przez Katedrę Dydaktyki i Edukacji 
Szkolnej w Instytucie Pedagogiki KUL. Nie zawiera całości prezentowanej problematyki, lecz wybrane kwestie.

Wyrażamy nadzieję, że zaprezentowane materiały staną się inspiracją do dalszych studiów i poszukiwań badawczych w zakresie pedagogiki wczesnoszkolnej i wczesnej edukacji.

Prof. dr hab. Krystyna Chatas e-mail: kryschal@kul.pl 